\title{
OPTIMIZATION AND MODELING OF A STAND-ALONE WIND/PV HYBRD ENERGY SYSTEM
}

\author{
Mohamed El Badawe1, Tariq Iqbal and George K. I. Mann \\ Faculty of Engineering and Applied Science, Memorial University of Newfoundland \\ ${ }^{1}$ Corresponding author: m.elbadawe@mun.ca
}

\begin{abstract}
Microwave repeaters are one of the main energy consumers in the telecommunication industry. These repeaters are powered using diesel generators and batteries, particularly when they are located in remote areas. Diesel generators require higher maintenance cost and for remote sites this cost will be more due to the added oil transportation cost. The aim of this paper to optimize and model a hybrid energy system for a microwave repeater located in Mulligan, Labrador, Canada. The hybrid system is a combination of wind, solar, diesel generation and batteries. Hybrid Optimization Model for Electric Renewable (HOMER) software is used for the sizing, and sensitivity analysis is performed in order to obtain the most feasible configuration of a hybrid renewable energy system. The proposed hybrid system is finally modeled in SIMULINK and results are presented to demonstrate the system performance.
\end{abstract}

Index Terms - renewable energy systems, microwave repeaters, pre-feasibility, photovoltaic, wind turbine, diesel generator.

\section{INTRODUCTION}

In the last few decades the world is experiencing higher prices of oil, which had caused several oil crises since early 70 s. Also, the world is experiencing many environmental issues related to usage of fossil fuel. For these reasons, the research and developments have increased to use renewable energy for generating power. [1], [2], [3], [4].

Communication technology is one of fastest growing technologies during these days. The telecommunication companies are continuously challenged to provide uninterrupted services to rural and remote areas where there are no reliable electrical power supply is available. Therefore, renewable energy systems are becoming increasingly popular in those industries to provide uninterruptible power to remote areas. Currently in most cases the telecommunication stations use diesel generators connected with backup batteries to provide power. As a result telecommunication companies are now attempting to provide uninterruptible power by using renewable energy resources. A typical example is that Bell-Aliant in Canada is using microwave repeater stations to deliver various services across all Atlantic provinces and it has already began using new green microwave stations [5], [6], [7], [8].

In this paper, a stand-alone hybrid alternative energy system is proposed for Bell-Aliant telecommunication site in Mulligan village in Labrador region, Canada. Currently this system uses diesel generator and batteries for power generation and we are proposing to improve the efficiency and operational costs of this system by integrating renewable energy sources using a wind turbine and a Photovoltaic (PV). In this case wind and PV are considered as the main power sources for the system and diesel generator and a battery pack are also integrated as a backup power supply. The diesel generator is treated as a mechanism to provide long-term power storage and the battery is used as a backup for short-term power storage. Sizing the system has done by HOMER then modeling has done in MATLAB/SIMULINK.

\section{SYSTEM SIZING}

The hybrid energy system sizing is done in Hybrid Optimization Model for Electrical Renewable (HOMER) software and a system implementation is shown in figure 1. The proposed system comprises primary renewable sources (Wind/PV) which are placed with a standby secondary nonrenewable sources (diesel generator/Batteries), and converter is included in the system to connect between $\mathrm{AC}$ and DC links. The system is designed specifically for an off grid system at remote area in Labrador region of Canada. The HOMER software is used to determine the best optimal sizing and pre-feasibility study of the system. Sensitivity analysis is considered when designing the system. 


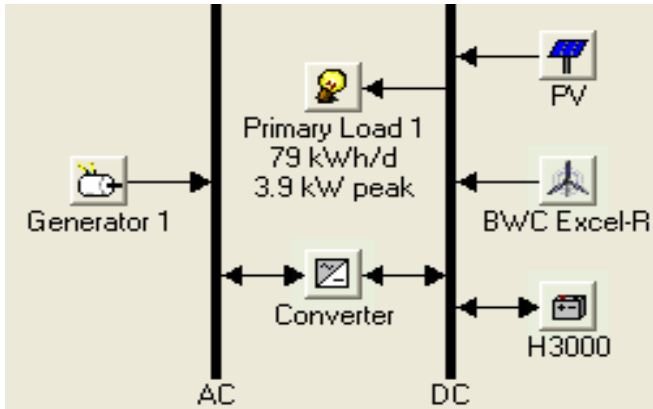

Fig.1 system implementation in Homer (PV-Photovotaic, BWC Ecell-RWind turbine, H3000-Battery, Generator 1- Diesel generator

\subsection{Electrical Load}

Mulligan site daily average DC load is 69A and the system runs on $48 \mathrm{~V}$ DC bus. So, the approximately power consumption at this site is $79.5 \mathrm{kWh} /$ day. Data Synthesizer is used to extract the data, and then use it in HOMER. The Data Synthesizer software can be used to generate three types of data that is wind, solar and load. It is known that telecommunication companies are operating continuously throughout the year. Therefore the hourly load is almost a constant as the consumption is same. Figure 2 shows a typical load profile for telecommunication site produced by HOMER. The detailed hourly variations of load data throughout the year are shown in figure 3 . It is clear that the variation is very small in some months; not more than $0.1 \mathrm{~kW}$. Most of the time, the variations in load is mainly due to the variation in using heaters and air conditioners of the system.

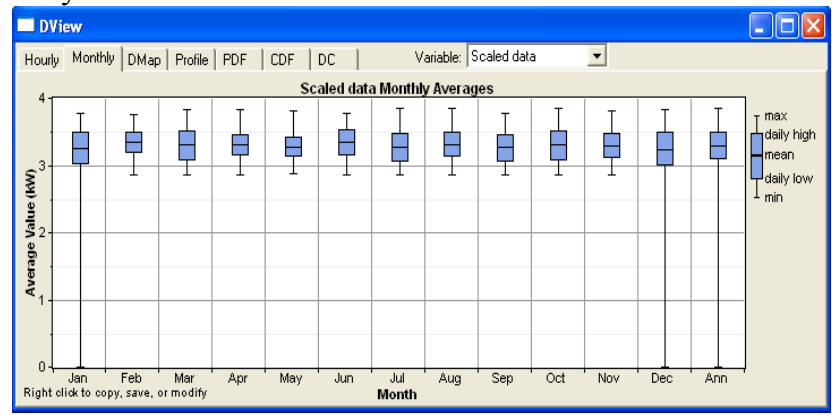

Fig.2 Load profile of Mulligan site

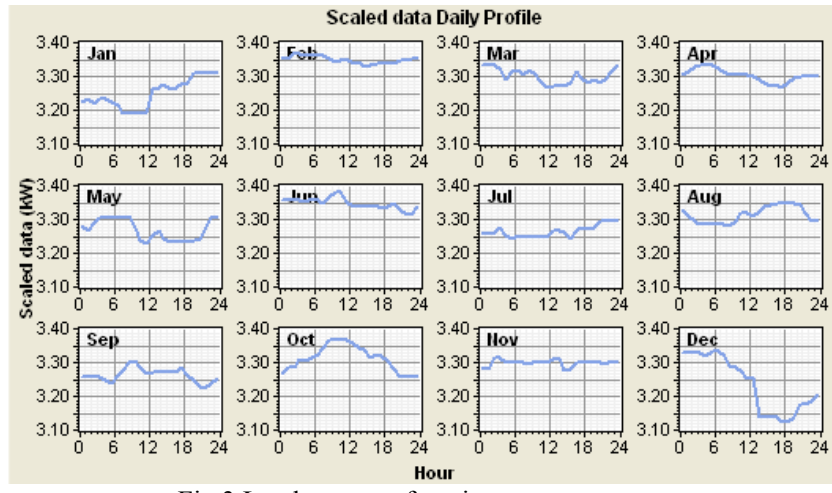

Fig.3 Load pattern of a microwave repeater

\subsection{Wind Turbine}

Two wind turbines from Bergey Wind Power having the model BWC-Excel-R/48 are used in this system. Each turbine has rated capacity of $7.5 \mathrm{~kW}$ and provides $48 \mathrm{~V}$ DC. The cost breakdown for the turbine is; capital cost is estimated as \$23081, replacement cost is estimated as $\$ 17000$, and annual operation and maintenance cost is estimated as $\$ 462$. The technical parameters of wind turbine were found from the data-sheets available from the same company. The hub height of 30 meters was selected. The HOMER software generated relationship (power curve) between the wind speed and the generated power, which is shown in figure 4 . Wind data of $10 \mathrm{~m}$ heights is used. The scaling up wind speed at Mulligan's telecommunication site is obtained as follows.

$U_{2}=U_{1}\left(\frac{h_{2}}{h_{1}}\right)^{\alpha}$

$U_{2}$ is scaled wind speed.

$U_{1}$ is wind speed data at highest h1.

$h_{1}$ is hub height

$h_{2}$ is reference height

$\alpha$ is Shear exponent, which can be found by

$\alpha=0.096 \log \left(Z_{0}\right)+0.016\left(\log Z_{0}\right)^{2}+0.24$

Figure 5 shows the wind speed data for Mulligan with $6.261 \mathrm{~m} / \mathrm{s}$ average wind speed. Three levels of wind speed are chosen for sensitivity analysis.

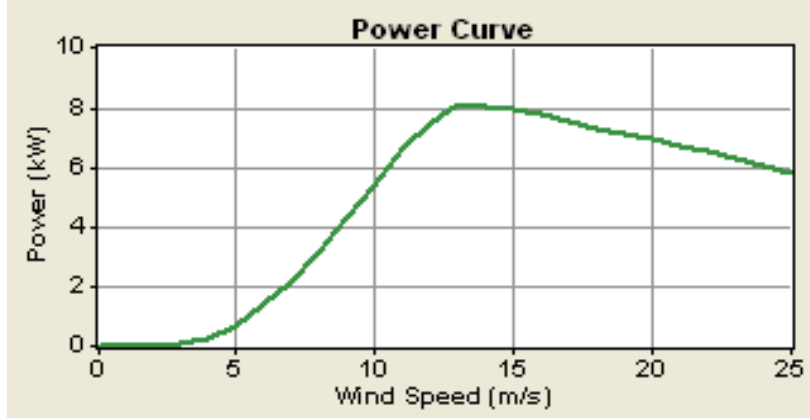

Fig.4 Wind turbine power curve

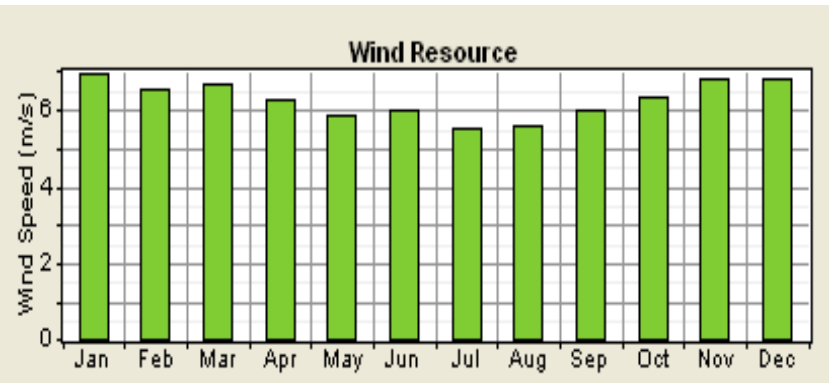

Fig.5 Average wind speed over a year 


\subsection{Photovoltaic Array}

The second renewable source implemented in this system is STP280-24/Vd solar module [13]. Each PV panel provides $280 \mathrm{~W}$ with $24 \mathrm{~V}$. So, two PV modules are connected in series to meet the bus voltage which is $48 \mathrm{~V}$. $6.5 \mathrm{~kW}$ PV rated capacity used in this system connected in 10 strings each one has two modules with twenty modules total. The initial cost of each two panels connect in series is $\$ 1745$, replacement cost is $\$ 1342$, and operational and maintenance cost is $\$ 52$. The latitude and longitude of Mulligan village are $53.86 \mathrm{~N}$ and $59.92 \mathrm{~W}$ respectively with time zone GMT3:30 Newfoundland. The effect of temperature is considered in this system. Figure 6 shows the solar radiation in a year produced by HOMER with $2.85 \mathrm{kWh} / \mathrm{m}^{2}-\mathrm{d}$ solar irradiation. These data was found from NASA website.

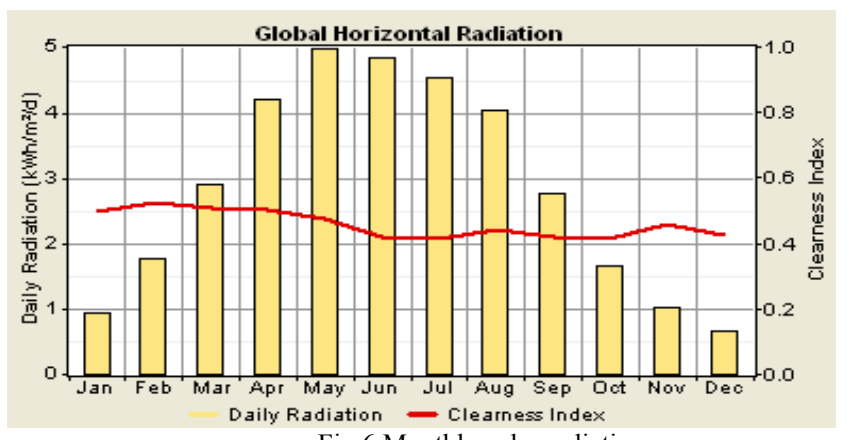

Fig.6 Monthly solar radiation

\subsection{Diesel Generator}

The first non-renewable source in this system is Perkins $404 \mathrm{C}-22 \mathrm{G}$ diesel generator. This generator is running at $1800 \mathrm{rpm}$ and used to deliver AC power to the system through the inverter. This generator has capacity of $20 \mathrm{~kW}$. From the data the initial capital cost is $\$ 16308$, replacement cost is $\$ 13590$, and operational and maintenance cost is $\$ 0.1 / \mathrm{hr}$. For this site the diesel can be transported only by air using a helicopter. Therefore the cost of diesel together with its transportation cost is approximated as $\$ 5$ per liter. The manufacture efficiency chart is shown in figure 7 and fuel consumption data for the generator is shown in table 1 . The diesel generator is used as a backup when wind/PV system is unable to produce sufficient power for the load.

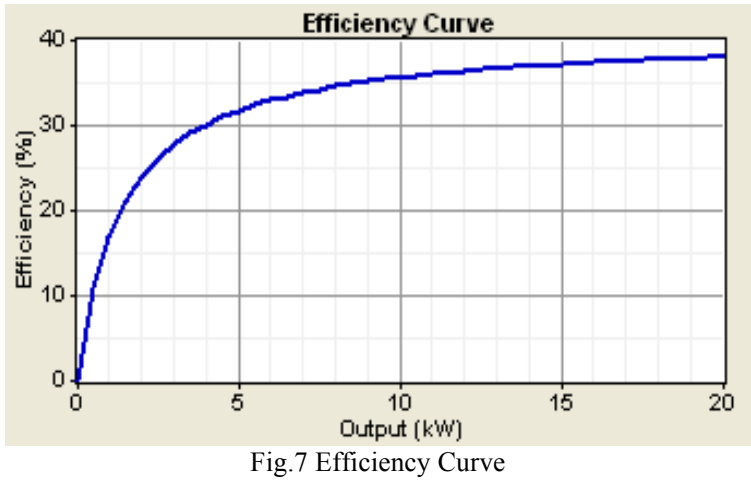

Table 1. Consumption Data

\begin{tabular}{|c|c|}
\hline $\begin{array}{c}\text { Output Power } \\
\text { (Kw) }\end{array}$ & $\begin{array}{c}\text { Fuel Consumption } \\
\text { (L/hr) }\end{array}$ \\
\hline 20 & 5.4 \\
\hline 15 & 4 \\
\hline 10 & 2.9 \\
\hline
\end{tabular}

\subsection{Battery}

Two strings of VRLA GNB XL3000 batteries are used at Mulligan each battery is $2 \mathrm{~V}$ and has a capacity $3000 \mathrm{Ah}$ with $48 \mathrm{~V}$ total bus voltage. These batteries are replaced every 10 years. The initial capital cost, replacement coast, and maintenance and operation coast of all batteries are $\$ 86000$, $\$ 60000$, and $\$ 100$ respectively

\subsection{Power Converter}

A converter is included in order to maintain the flow of energy between the AC and the DC bus. The conventional load is DC type, but generated power from diesel generator is AC type. The size of the convertor that is used in this system is $7 \mathrm{~kW}$. The initial capital cost and replacement cost are $\$ 2500$ and $\$ 1500$ respectively.

\subsection{Optimized Results}

HOMER software performs several simulations in order to obtain the optimal hybrid system. Four sensitivity variables are considered in this system and they are wind speed, solar irradiation, load, and diesel price and each of these variables has three different values. Therefore 81 sensitivity cases have been tested in the system configuration. HOMER identified the best possible configuration for the hybrid system. Figure 8 shows five optimization results for the hybrid renewable energy system. The one having the lowest overall cost is selected in this exercise. In this chosen system the initial capital cost (IC) is $\$ 968,420$, Total Net Present Cost (TNPC) is $\$ 1,011,514$, and Cost of Energy (COE) is $\$ 3.385 / \mathrm{kWh}$. Figure 9 shows the monthly average electric production of the system. Photovoltaic production is $14 \%$, diesel generator production is $2 \%$, and wind turbine is supplied the rest of the load which is $84 \%$.

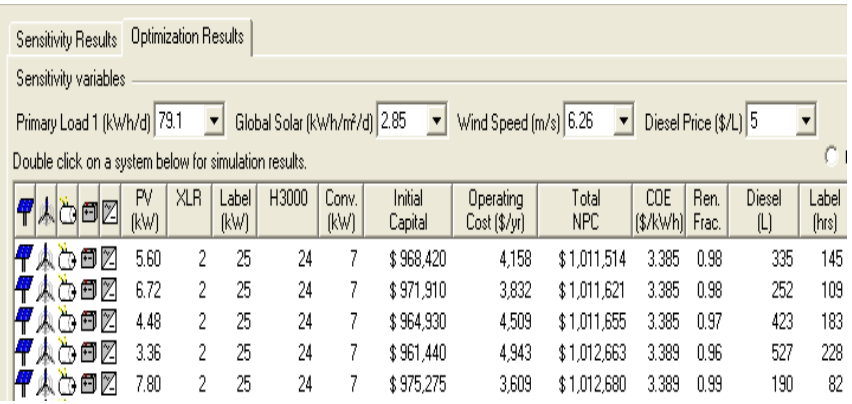

Fig.8 Optimization results with sensitivity variables 


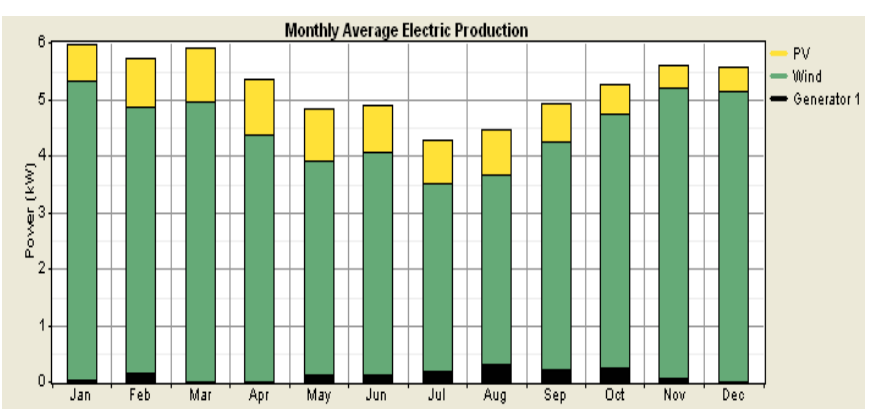

Fig.9 Monthly average electric production

\section{DYNAMIC MODELING RESULTS}

Energy power management strategies and dynamic models of the proposed hybrid system have been developed using MATLAB/SIMULINK to investigate the system performance.

\subsection{Wind Turbine}

The hourly output of wind generator depends on the hourly average of wind speed at the hub height. The output power of wind generator can be expressed as [12].

$P_{W_{T}}=\frac{1}{2} \rho C_{p}(\lambda, \theta) A V^{3}$

Where,

$P_{W_{T}}$ is output power

$\rho$ is air density in $\mathrm{Kg} / \mathrm{m}^{3}$

$C_{p}$ is power coefficient and is a function of tip speed ratio

$(\lambda)$ and pitch angle $(\theta)$.

$A$ is wind turbine area

$V$ is wind speed

Permanent magnet synchronous generator was used to get the wind power. The whole system block diagram of wind turbine is shown in figure 10 and the power curve of the wind turbine, which has $7500 \mathrm{~W}$ rated power is shown in Figure 11.

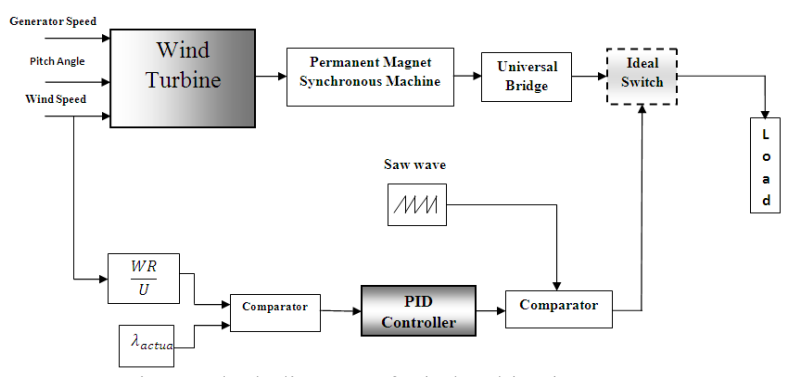

Fig.10 Block diagram of wind turbine in SIMULINK

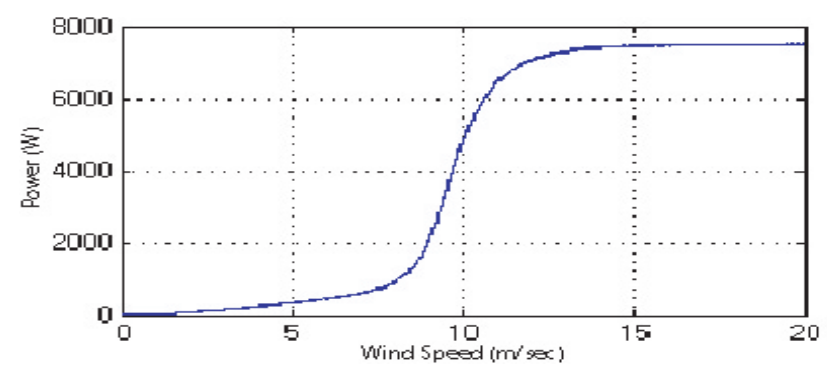

Fig.11 Wind turbine power curve

\subsection{Photovoltaic}

A solar cell module is the basic element of photovoltaic system. The solar cell model consists of a diode, a current source, a series resistance and parallel resistance as shown in figure 12. The energy variables for the solar system are radiation and temperature. Equation (3) shows an expression for the solar module [13] and it is a function of solar radiation and ambient temperature. The diode is used to represent the p-n junction of the solar cell [13].

$I=I_{P h}-I_{S} *\left[\exp \left\{q *\left(V+I R_{S}\right) /\left(K * T_{C} * A\right)\right\}-\right]-$

$\left[\left(V+I R_{S}\right) / R_{S H}\right]$

Where

$I$ is cell output current, $V$ is cell output voltage, $I_{S}$ is saturation current, $q$ is electronic charge $\left(0.6039 \exp ^{(-19)} C\right), \quad R_{S}$ is a series resistance, $K$ is Boltzmann's constant $(1.38 \exp (-23) \mathrm{J} / \mathrm{K}), \quad T_{C}$ is cell temperature, $A$ is an ideal factor $(=1.740)$, and $R_{S H}$ is a shunt resistance (parallel resistance $=\infty$ ). The photocurrent mainly depends on the solar insolation and cell's working temperature, which is described as

$I_{P h}=\left[I_{S C}+K_{t}\left(T_{C}-T_{R e f}\right)\right] \lambda$

Where:

$I_{S C}$ is short circuit current, $K_{t}$ is the short-circuit current temperature coefficient $(\mathrm{A} / \mathrm{C}) . T_{R e f}$ is the room temperature $25^{\circ} \mathrm{C}$, and $\lambda$ is a solar irradiation in $\mathrm{W} / \mathrm{m}^{2}$. The cell's saturation current describes as

$I_{S}=I_{R S}\left(T_{C} / T_{R e f}\right)^{3} \exp \left[q E_{G}\left(\frac{1}{T_{R e f}}-1 / T_{C}\right) / k A\right]$

Where:

$I_{R S}$ is the cell's reverse saturation current, $E_{G}$ is the band gap for silicon $(=1.12 \mathrm{eV})$,

$\mathrm{I}-\mathrm{V}$ output characteristics and $\mathrm{P}-\mathrm{V}$ output characteristics with $1000\left(\mathrm{w} / \mathrm{m}^{2}\right)$ radiation intensity and $25^{\circ} \mathrm{C}$ ambient temperature are shown in figure 13 respectively. These PV modules give $5600 \mathrm{~W}$. The open circuit voltage (Voc) is $44.8 \mathrm{~V}$. 


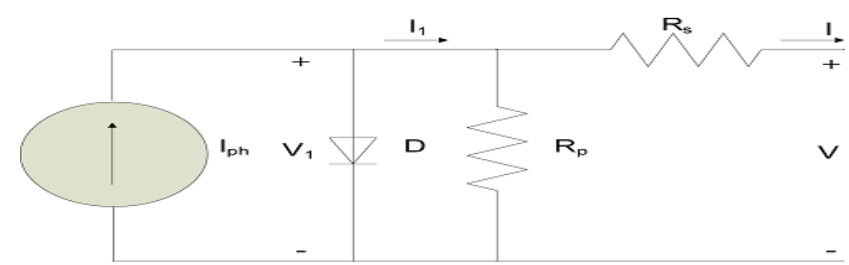

Fig.12 Solar cell model.
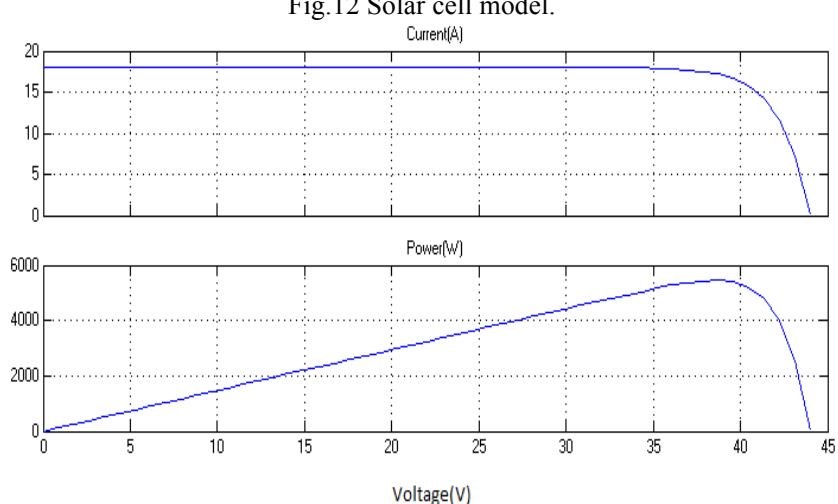

Fig.13 I-V and P-V output characteristics of PV module

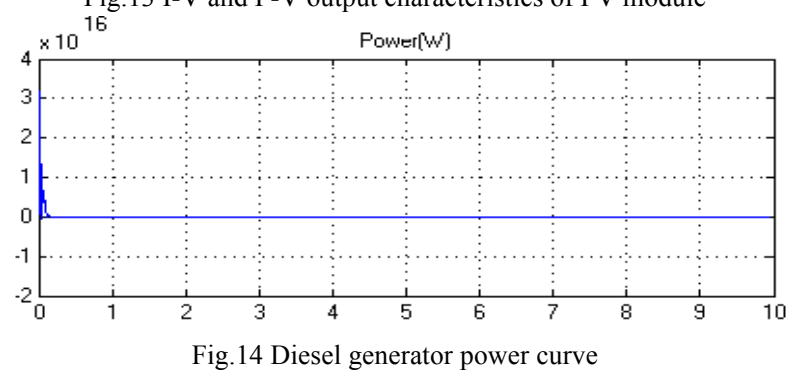

\subsection{Diesel Generator}

The main purpose of the diesel generator is to use as a backup energy sources when the renewable resources under performs. The sizing results shows the energy production from the generator is around $2 \%$ of the total power demand and figure 14 shows the simulation results of diesel production.

\section{SIMULATION RESULTS}

System configuration of the proposed alternative hybrid energy system is shown in figure 15. This proposed system has been implemented in MATLAB/SIMULINK to investigate the performance. The model includes $7.5 \mathrm{~kW}$ wind turbine, $5.6 \mathrm{~kW} \mathrm{PV}, 20 \mathrm{~kW}$ diesel generator, and $48 \mathrm{~V}$ battery. All of these components are connected to the load, and also connected to the dump load to control the system. The load size results are presented in figure 16 and it constitutes current, voltage and power from the overall output. The variation here is very low because the site has the same load daily. The wind speed input is a step response with $10 \mathrm{~m} / \mathrm{sec}$ initial value to $12 \mathrm{~m} / \mathrm{sec}$ final value when step time is 2 . Therefore, the power changes from $3.05 \mathrm{~kW}$ when the wind speed is $10 \mathrm{~m} / \mathrm{sec}$ to $3.25 \mathrm{~kW}$ when the wind speed is $12 \mathrm{~m} / \mathrm{sec}$. Dynamic simulation is still a work in progress.
More results will be presented in the final version of the paper.

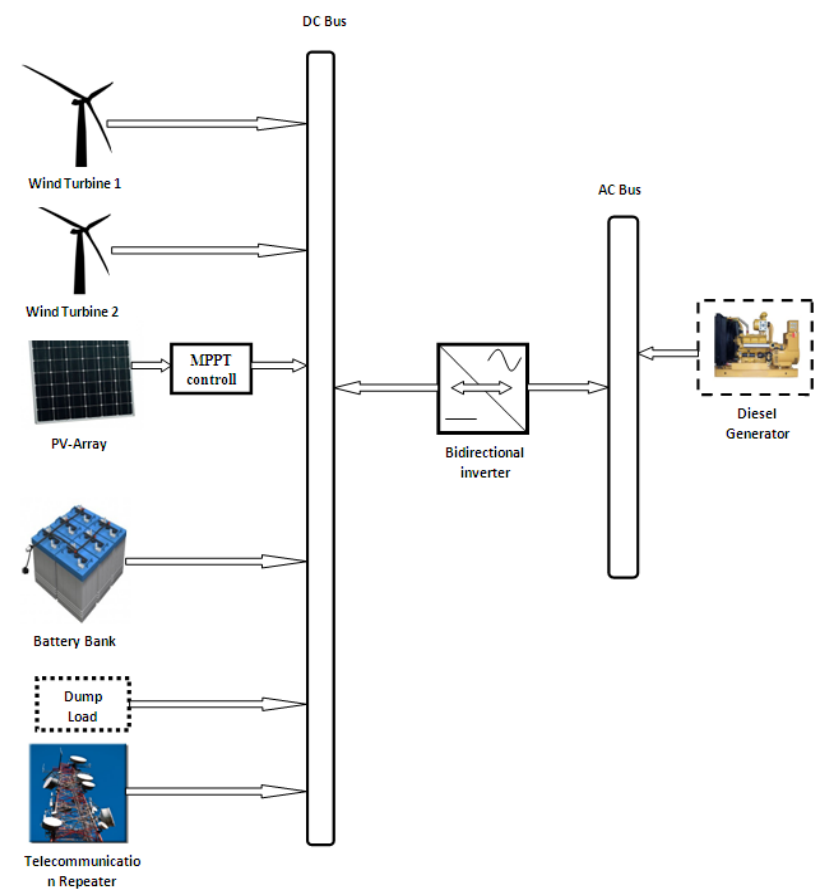

Fig.15 System configuration of the proposed alternative hybrid energy system
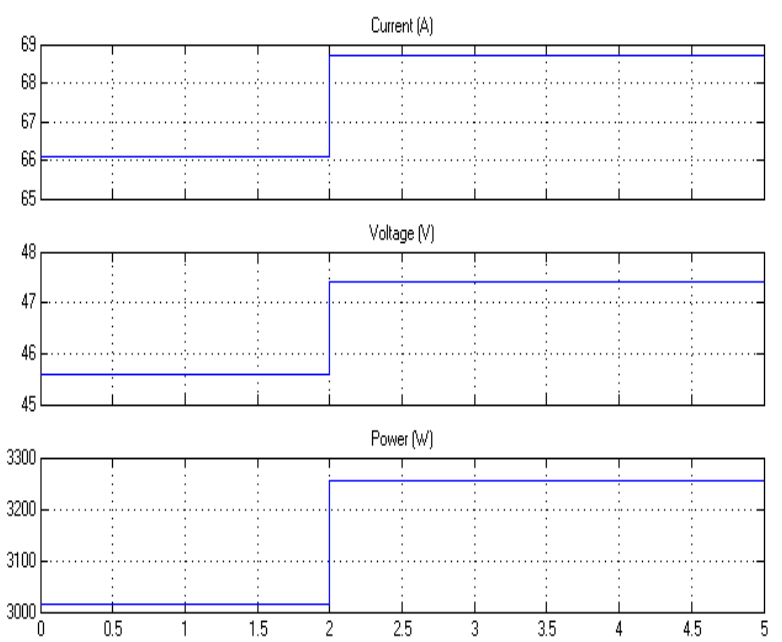

Fig.16 Current, voltage, and power of the system

\section{CONCLUSION}

This paper presented a proposed hybrid power system for a remote telecommunication site in Labrador. System sizing and designed system configuration is presented. It is shown that hybrid energy system for that site can have a renewable energy fraction of $98 \%$. Dynamic modeling of the proposed hybrid system in Simulink is also presented. Transient response indicates a stable results. 


\section{ACKNOWLEDGMENTS}

The authors would like to thank Ministry of Education and Scientific Research of Libya for giving the corresponding author a scholarship to finish his master at Memorial University of Newfoundland and Mr. Stephen Smith who works with Bell Aliant for providing the site load data, location, and configuration information.

\section{REFERENCES}

[1]. Belfkira, R.; Nichita, C.; Barakat, G, "Modeling and optimization of wind/PV system for stand-alone site", 18th International Conference on Electrical Machines, 2008. ICEM 2008, pp 1-6, Sept 6-9, 2008.

[2]. Lagorse, J; Giurgea, S; Paire, D; Cirrincione, M; Simoes, M.G; Miraoui, A; , "Optimal Design Analysis of a Stand-Alone Photovoltaic Hybrid System", IEEE Industry Applications Society Annual Meeting, 2008. IAS '08, pp1-7, Oct 5-9, 2008.

[3]. Hung-Cheng Chen, Jian-Cong Qiu, and Chia-Hao Liu, "Dynamic modeling and simulation of renewable energy based hybrid power

systems", Third International Conference on Electric Utility Deregulation and Restructuring and Power Technologies, 2008. DRPT 2008, pp 28032809, April 6-9, 2008.

[4]. Razak, N.A.b.A.; bin Othman, M.M.; Musirin, I; , "Optimal sizing and operational strategy of hybrid renewable energy system using homer", 4th International Power Engineering and Optimization Conference (PEOCO), 2010, pp495-501, June 23-24, 2010.

[5]. Karshenas, H. ; Karimi-Ghartemani, M. ; Yazdani, D. ; Khajehoddin, S.A. ; Zaman, M. ;Bakhshai, A. ; Jani, P; , "A Hybrid Renewable Energy System for powering Information and Communication Technology (ICT)", 32nd International Telecommunications Energy Conference (INTELEC),

pp1-6, June 6-10, 2010.

[6]. Picklesimer, D. ; Rowley, P. ; Parish, D. ; Carroll, S. ; Bojja, H.; Whitley, J.N; , "Techno-economic optimization of sustainable power for telecommunications facilities using a systems approach", International Symposium on Sustainable Systems and Technology (ISSST), 2010 IEEE, pp1-6, May 17-19, 2010.

[7]. J.K. Kaldellis, "Optimum hybrid photovoltaic-based solution for remote telecommunication stations", Renewable Energy, Vol, 35, Pages 2307-2315, October 2010.

[8]. Smith, S.S.; Iqbal, M.T; , "Design and Control of a Hybrid Energy System for a Remote Telecommunication Facility ", presented at IEEE 17, NECEC conference, St.John's NF, 2007.

[9]. Reaz U1 Haque ; M. T. Iqbal ; John E. Quaicoe ; "Sizing, Dynamic Modeling and Power Electronics of a Hybrid Energy System", Canadian Conference on Electrical and Computer Engineering, 2006. CCECE '06. , pp1135-1138, May 2006.

[10]. Juhari Ab. Razak, Kamaruzzaman Sopian, Yusoff Ali, "Optimization of Renewable Energy Hybrid System by Minimizing Excess Capacity", INTERNATIONAL JOURNAL OF ENERGY, Vol. 1, 2007.

[11]. Bajpai, P. ; Kumar, S. ; Kishore, N.K.; "Sizing optimization and analysis of a stand-alone WTG system using hybrid energy storage technologies", International Conference on Energy and Sustainable Development: Issues and Strategies (ESD 2010), pp1-6, June 2-4, 2010.

[12]. Furat Abdal; Rassul Abbas; Mohammed Abdulla Abdulsada; "Simulation of Wind-Turbine Speed Control by MATLAB", International Journal of Computer and Electrical Engineering, Vol. 2, October, 2010 [13]. P.S.Revankar; W.Z.Gandhare; and A.G. Thosar, "Maximum Power Point Tracking for PV Systems Using Matlab/Simulink", Second International Conference on Machine Learning and Computing (ICMLC), 2010, pp8-11, Feb 9-11, 2010 